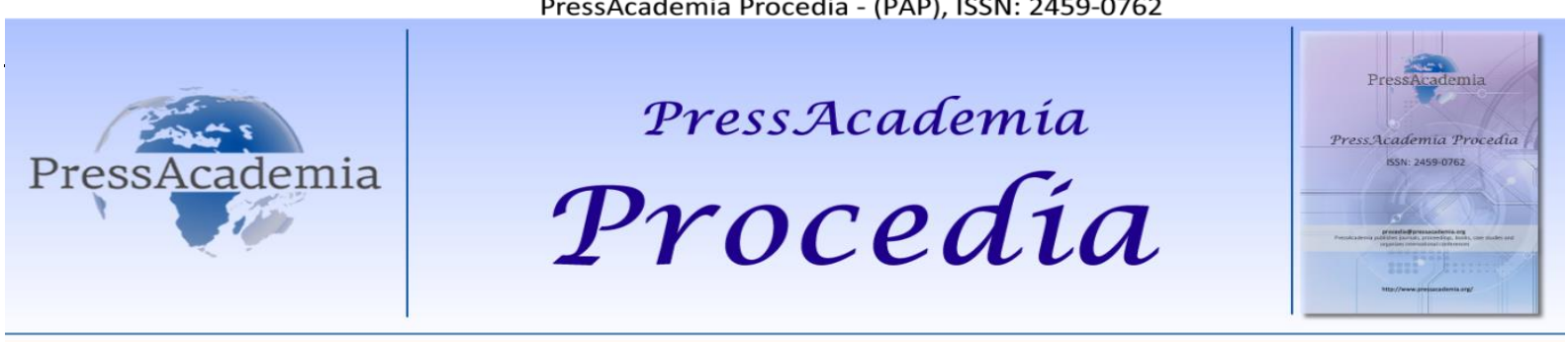

Global Business Research Congress (GBRC), May 24-25, 2017, Istanbul, Turkey.

\title{
MOBBING IN TURKISH LABOR LAW
}

\author{
DOI: 10.17261/Pressacademia.2017.427 \\ PAP-GBRC-V.3-2017(42)-p.409-422
}

\section{Yusuf Erdem Tunc}

Marmara Üniversitesi, İktisat Fakültesi, Çalışma Ekonomisi Bölümü, Kadıköy, İstanbul, Türkiye. y.erdem.t@hotmail.com

\section{To cite this document}

Tunc, Y. (2017). Mobbing in Turkish labor law. PressAcademia Procedia (PAP), V.3, p.409-422

Permemant link to this document: http://doi.org/10.17261/Pressacademia.2017.427

Copyright: Published by PressAcademia and limited licenced re-use rights only.

\begin{abstract}
Although the Labor Code is not a direct regulation of mobbing, the worker protective structure of the Labor Code creates a protective structure if it is inadequate against some behaviors that can be described as mobbing. A worker who is incompatible with the cost of equal treatment may claim another compensation for a compensation fee of up to four months. In accordance with Article $24 / 2$ / b of the Labor Code, if the words to be said for the honor and honor of the worker are spoken or if they are committed, the worker's employment contract may be terminated for good cause before the end of the employee or without waiting for the notification period. The employer can also make mobbing by making constant changes in working conditions. According to the Labor Code m.22; If the employer makes a significant change in the working conditions, he must report the situation in writing to the worker. Changes that the worker does not accept in writing do not affect the worker.
\end{abstract}

Keywords: Mobbing, physchological violence, bullying at work, labor law, coping with mobbing JEL Codes: K31, D23, J01

\section{TÜRK IŞ HUKUKUNDA MOBBING}

\section{ÖZET}

İ̧ Kanunu'nda mobbingle ilgili doğrudan doğruya bir düzenleme olmamakla birlikte İş Kanunu'nun iş̧̧iyi koruyucu yapısı, mobbing olarak nitelendirilebilecek kimi davranışlara karşı yetersizde olsa koruyucu bir yapı oluşturmaktadır. Eşit davranma borcuna aykırılıkla karşılaşan iş̧̧ dört aya kadar ücreti tutarında bir tazminattan başka yoksun bırakıldığı haklarını da talep edebilir. iş Kanunu m.24/2/b 'ye göre iş̧̧inin şeref ve namusuna dokunacak sözler söylenilmesi veya davranışlarda bulunulması durumunda iş̧̧i iş sözleşmesi sürenin bitiminden önce veya bildirim süresini beklemeksizin haklı nedenle feshedebilir. İşveren çalışma koşullarında sürekli değişiklikler yaparak da mobbing yapabilir. İ̧ Kanunu m.22'ye göre; işveren çalışma koşullarında esaslı bir değişiklik yapacak olursa durumu iş̧̧iye yazılı olarak bildirmek zorundadır. Iş̧̧inin yazııı olarak kabul etmediği değişiklikler işçiyi bağlamamaktadır.

Anahtar Kelimeler: Mobbing, psikolojik şiddet, işyerinde zorbalık, iş hukuku, mobbing ile başaçıkma JEL Kodları: K31, D23, J01

\section{GiRiş}

Mobbing günümüzde sıkça karşılaşılan çok yönlü, multidisipliner bir kavramdır. Psikolojik, sosyal, kültürel boyutuna ek olarak hukuksal boyutu da bulunmaktadır. Bireylere ve topluma çeşitli boyutlarda zarar veren mobbing kavramına yönelik hukuksal düzenlemelerin yapılması kaçınılmazdır.

Mobbing, işyerinde bir veya birden fazla kişi tarafından diğer kişi ya da kişilere yönelik gerçekleştirilen, belirli bir süre sistematik biçimde devam eden, yıldırma, pasifize etme veya işten uzaklaştırmayı amaçlayan; mağdur veya mağdurların 
kişilik değerlerine, mesleki durumlarına, sosyal ilişkilerine veya sağılılarına zarar veren; kötü niyetli, kasıtlı, olumsuz tutum ve davranışlar bütünüdür.

Türk hukukunda mobbinge yönelik düzenlemeler bulunmakla birlikte, mobbingin tanımlanması Yargıtay kararlarına bırakılmıştır. Biz bu çalışmamızda mobbing kavramını çok yönlü bir şekilde almak suretiyle öncelikle mobbingi hukuksal boyutu dışındaki boyutlarıyla incelemiş bulunmaktayız. Ardından Türk Hukukunda; İ̧ Kanunu, Türk Borçlar Kanunu, İ̧ Sağlığı ve Güvenliği Kanunu, Türk Medeni Kanunu ve Türk Ceza Kanunundaki yansımalarını inceleyip Yargıtay kararları ile destekledik.

\section{MOBBING KAVRAMI}

Çalışma hayatının başlarından beri karşılaşılan ancak günümüzde işçilere, iş verimine ve üretim kalitesine etkisinin fark edilmesiyle birlikte yazıı ıe görsel basında sıkça karşılaştığımız "psikolojik taciz" bir diğer adıyla "mobbing" kavramının literatürde üzerinde anlaşılan bir tanımı yoktur. Terim ilk kez 19. Yüzyılda, biyologlar tarafından, " yuvalarını korumak için saldırganın etrafını saran kuşların davranışları”nı nitelemek amacıyla kullanıımıştır. ${ }^{1}$

Mobbing'in iş yaşamındaki karşıı̆ıın kapsayacak şekilde ilk kullanımı Heinz Leymann tarafından gerçekleştirilmiş olup Leymann mobbingi; bir veya birkaç kişi tarafından bir çok sebeple bir kişiye yönelik olarak, sistematik bir biçimde, düşmanca, ahlak dışı bir iletişim yöneltilmesi şeklinde ortaya çıkan psikolojik terör olarak tanımlamıştır. ${ }^{2}$ Leymann'a göre; sözkonusu düşmanlık içeren ahlak dışı davranış, bir örgütte, 6 aydan fazla süre ile haftada en az 1 kere, bir veya daha fazla kişi tarafından gerçekleştirilmelidir. ${ }^{3}$

ILO’ya göre mobbing; hedef bir çalışanın bir grup çalışanın psikolojik tacizine maruz kalmasıdır. Bu kişi hakkında sürekli olarak olumsuz yorumlarda bulunulmakta ve sürekli olarak eleştirilmektedir. Buna ek olarak bu kişi sosyal olarak dışlanmakta, hakkında yanlış bilgiler dağıtılmakta ya da sürekli bir şekilde alay edilmektedir. ${ }^{4}$

Bir başka tanıma göre mobbing; duygusal bir saldırıdır. Bir grup kişi sistematik baskılarda bulunarak, diğer bir kişiye karşı ahlaki olmayan davranışlarda bulunmakta, itibarını zedelemekte ve dayanma gücünü yok ederek onu işten ayrılmaya zorlamaktadır. $^{5}$

Çalışma ve Sosyal Güvenlik Bakanlığının yayınladı̆̆ı İ̧yerinde Psikolojik Şiddet Taciz (Mobbing) Bilgilendirme Rehberine göre mobbing; "Iş̧yerinde bir veya birden fazla kişi tarafından diğer kişi ya da kişilere yönelik gerçekleştirilen, belirli bir süre sistematik biçimde devam eden, yıldırma, pasifize etme veya işten uzaklaştırmayı amaçlayan; mağdur veya mağdurların kişilik değerlerine, mesleki durumlarına, sosyal ilişkilerine veya sağlıklarına zarar veren; kötü niyetli, kasıtlı, olumsuz tutum ve davranışlar bütünüdür." ${ }^{6}$

Bir başka tanıma göre mobbing; bir ya da daha fazla kişinin, din, dil, ırk, cinsiyet ayrımı gözeterek düşmanca ve ahlak dışı yaklaşımlarla çalışana yönelik olarak psikolojik şiddet ve baskı yapmasıdır. Bu davranış kişiye fiziksel ve psikolojik zararlar vererek aylar hatta yıllarca sürmekte ve yetişkinler arasında, yöneticiler arasında ve hatta aynı statüye sahip çalışanlar arasında yaşanmaktadır. ${ }^{7}$

Bir diğer tanıma göre mobbing; "iş̧̧ilerin birbirlerine ya da işveren veya işveren vekillerinin işçilere karşı sistematik olarak ve uzun bir süreden beri düşmanlık beslemesi, kasten güçlük çıkarması, eziyet veya tehdit etmesi, aşağılaması gibi davranışlarla iş̧̧iyi işyerinde çalışmaktan bezdiren ve sosyal ortamdan uzaklaştıran davranışlardır." ${ }^{8}$

\footnotetext{
${ }^{1}$ Tınaz, Pınar, İşyerinde Psikolojik Taciz(Mobbing), Beta Yayınevi, İstanbul, 2010, s.10

${ }^{2}$ Tınaz, Pınar; Ergin, Hediye; Bayram, Hediye, Çalışma Psikolojisi ve Hukuki Boyutlarıyla İşyerinde Psikolojik Taciz (Mobbing), Beta Yayınevi, ìstanbul, 2008, s.5

${ }^{3}$ Leyymann, Heinz, "The Content and Development of Mobbing at Work", Eurpean Journal of Work and Organizational Psychology", 1996, 5(2), s.168

${ }^{4}$ Chappell, Duncan ve Di Martino, Vittorio, Violence at Work, International Labour Office, Genava, 2006, s.22; Bir davranışın mobbing olarak nitelendirilebilmesi için sürekli olması gerekmektedir. Yargıtay 9. HD kararına göre; işyerinden çıkışına izin verilmeyen işçinin çantasının aranmak istenmesi ve bu arada güvenlik görevlisinin fiili saldırısı süreklilik koşulunu karşılamamaktadır (Yarg. 9. HD. 04/02/2014 E. 2012/2473 K. 2014/2959). Bir diğer karara göre süreklilik göstermeyen, belli aralıklarla sık sık tekrarlanmayan, ara sıra münferit olarak meydana gelmiş haksız, kaba, nezaketsiz veya etik dışı davranışlar mobbing olarak nitelendirilemez (Yarg. 22. HD. 27/02/2014 E. 2014/3426 K. 2014/4165).

${ }^{5}$ Davenport, Noa; Schwartz, Ruth Distler, Elliot, Gail Pursell, Mobbing işsyerinde Duygusal Taciz, Sistem Yayınclık, ìstanbul, 2003 , s.15 ${ }^{6}$ Iş̧yerinde Psikolojik Şiddet Taciz (Mobbing) Bilgilendirme Rehberi, https://www.csgb.gov.tr/media/2053/mobbing_2014.pdf, s.9, Erişim Tarihi: 15.02 .2016

'Zapf, D.; Konrz, C.; Kulla, M., "On the Relationship Between Mobbing Factors and Job Content The Social Work Environment and Healthe Outcomes", European Journal of Work and Organizational Psychology, 5, s.217

${ }^{8}$ Sümer, Haluk Hadi, İ̧ Hukuku, Seçkin Yayınevi, Ankara, 2016, s.88
} 
Literatürde mobbing kavramı yerine bullying (zorbalık), work or employee abuse (iş veya işgören tacizi), mistreatment (kötü muamele), intimidation (korkutma), verbal abuse (sözlü taciz), horizontonal violance (yatay şiddet), psikolojik terör, psikolojik şiddet gibi terimlerde kullanılmaktadır. ${ }^{9}$

Türk Dil Kurumu ise mobbing kavramına alternatif olarak "Bezdiri" kelimesini önermiş ve şu şekilde tanımlamıştır; " iş yerlerinde, okullarda vb. topluluklar içinde belirli bir kişiyi hedef alıp, çalışmalarını sistemli bir biçimde engelleyip huzursuz olmasına yol açarak yıldırma, dışlama, gözden düşürme" ${ }^{10}$

Bir davranışın mobbing olarak kabul edilebilmesi için aşağıdaki ölçütler gerekmektedir; ${ }^{11}$

- Davranışın sürekli ve sistemli olması,

- Kişinin maddi ve manevi bütünlüğüne zarar vermeye yönelik olması,

- Davranışın mağdur üzerinde olumsuz etkilerinin olması,

- Davranışın kasti olarak yapılması

Mobbing mesleği tehdit edici unsurlar içerir, ${ }^{12}$ kişiliği tehdit edici unsurlar içerir, mesleki gelişimi engelleyici davranışlar içerir, iş yükü artırılır ${ }^{13}$, engeller konur ${ }^{14}$ ve hedef şaşırtıcı hamlelerde bulunulur. ${ }^{15}$

Mobbing çok çeşitli davranışlar aracılığı ile yapılabilmektedir. Kişinin kişisel ve profesyonel performansına yönelik saldırılar, telefon konuşmalarının engellenmesi veya dinlenmesi, masasının ve ofis düzeninin değiştirilmesi, toplantılardan dışlanması, sürekli bağırılması, eleştirilmesi, işçinin sürekli yük altına sokulması, tecrit edilmesi, ${ }^{16}$ özel kutlama ve davetlere kasıtlı olarak davet edilmemesi, hakkında asılsız söylentiler çıkarılması gibi davranışlarda bulunulabilmektedir. ${ }^{17}$

Söz konusu davranışlar tek tek ele alındığında hukuka aykırı fiil oluşturmayabilir. Ancak sistematik ve tekrarlanan şekilde yapıldığında suç oluşturmaktadır. ${ }^{18}$

Mobbing sonucunda mobbingle karşılan kişide iş stresi başlar, işe gitmeme eğilimi artar. Strese bağlı sağlık sorunlarının tehdidi altına girer. Depresyon, panik atak krizleri, yüksek tansiyon, dikkati toplayamama, baş ağrıları, mide rahatsızlıkları, iştahsızlık vb. problemlerle karşılaşır. ${ }^{19}$ Birçok araştırma göstermektedir ki mobbing, tüm stres kaynaklarından daha yoğun ve yıkıcı etki göstermektedir. ${ }^{20}$

\section{MOBBING ILE HUKUKI MÜCADELE}

Mobbing sürecinin bireysel, örgütsel, toplumsal ve ekonomik sonuçları doğmaktadır. Ancak bu sonuçlar arasında en yıkıcı olan bireysel sonuçlardır. Bir başka deyişle mağdur bu sürecin en çok etkilenenidir. İşyerinde dışlanan ve mesleki kimliğini yitirmiş kişi sosyal çevresindeki yerine ve değerini de yitirmektedir. ${ }^{21}$ Çünkü mobbing mağduru ister istemez içinde bulunduğu sürecin sebep olduğu mutsuzluğu ailesi ve sosyal çevresine de yansıtacaktır.

\footnotetext{
${ }^{9}$ Yamada, David, “Global Perspective on Workplace Harassment Law: Proceedings of The 2004 Annual Meeting, Association of American Law Schools Section On Labor Relations and Emploment Law", Employee Rights and Employement Policy Journal, 2004, 8(1), s.180; TInaz, İsyerinde Psikolojik Taciz (Mobbing), 2010, s.15

${ }^{10}$ Türkiye Büyük Millet Meclisi, Kadın ve Erkek Fırsat Eşitliği Komisyonu, TBMM Basımevi, Ankara, 2010

${ }^{11}$ Aydın, Şule; Özkul, Emrah, "İşyerinde Yaşanan Psikolojik Şiddetin Yapısı ve Boyutları: 4-5 Yıldızlı Otel İşletmeleri Örneği”, Anadolu Üniversitesi Sosyal Bilimler Dergisi, 7(2), s.171

${ }^{12}$ işveren kişisel nedenlerle iş̧̧inin yanında çalışmasını istememektedir. Bu sebeple bir yıl içinde 5 kez yazılı savunma talep etmiştir. İşveren davacıyı iş arkadaşlarının önünde sürekli bir şekilde küçük düşürmüş, bağırmış ve işleri beceremediğini ifade etmiştir. Mobbing kavramı, işyerinde bireylere üstleri, eşit düzeyde çalışanlar ya da astları tarafından sistematik biçimde uygulanan her tür kötü muamele, tehdit, şiddet, aşağılama vb. davranışları içermektedir. Açıklanan olaylar ışığında davacının davasının kabulü gerekir. (Yarg. 9. HD. E. 2007/9154 K.2008/13307

13 “... Davacının davalı işyerinde muhasebe elemanı olarak çalıştı̆̆ı sırada temizlik elemanı olarak temizlik işlerine verildiği, davacının yeni verildiği bu işyerinde işbaşı yapmayarak hizmet akdini sona erdirdiği, iş değişikliği sebebiyle davacının çalışma şartları ağırlaştı̆̆ından davacının feshinin 1475 sayılı Yasanın 16/II. Maddesine uygun düştüğünden kıdem tazminatının kabulü doğru ise de feshi gerçekleştirdiği anlaşılan davacı lehine ihbar tazminatının verilmesi hatalı olup bozmayı gerektirmiştir", Yarg. 9. HD. 24/01/2002 E. 2001/16224

14 “Kocaeli Üniversitesi (KOÜ) Hukuk Fakültesi Dekanı Prof. Dr. Zehra Gönül Bakır, aralarında kişisel husumet bulunan Yrd. Doç. Dr. Mustafa Çakır'ı uluslararası bir kongreye göndermeyerek psikolojik baskı (mobbing) uyguladığı gerekçesiyle 3 bin TL manevi tazminat ödemeye mahkum edildi." http://www.milliyet.com.tr/dekana-mobbing-cezasi-gundem-1270035/, Erişim Tarihi: 10.04.2017

${ }^{15}$ Rayner, Charlotte ve Hoel, Helge, “Workplace Bullying”, Journal of Community \& Applied Social Psychology, 1997, 10(4), s.181-191

${ }^{16}$ Davacının işyerinde yalnızlaştıııımaya çalışılması mobbingdir (Yarg. HGK. 02/11/2011, E. 2011/9-590 K. 2011/677).

${ }^{17}$ Adams, Andrea, Bullying at Work, Journal of Community \& Applied Social Psychology, 1997, 7, s. 178; Süzek, Sarper, iş̧ hukuku, Beta Basım Yayım, i̇stanbul, 2013, s.408

${ }^{18}$ Süzek, İ̧ Hukuku, s.408

${ }^{19}$ Tınaz, Pınar, Mobbing: İşyerinde Psikolojik Taciz, Çalışma ve Toplum, 2006, 3/10, s.18;

${ }^{20}$ Keser, Aşkın, Çalışma Psikolojisi, Ekin Yayınevi, Bursa, 2012, s.201

${ }^{21}$ Tınaz, Mobbing: İşyerinde Psikolojik Taciz, s.154
} 
Mobbing davranışlarının sıkça karşılaşılan bir olgu haline gelişi ve birçok zararlı sonucu sebebiyle önüne geçilmesi gerekli hale gelmiştir. Mobbingin önlenmesine yönelik bireysel ve örgütsel önlemler alınabileceği gibi hukuki önlemler de alınmalıdır. Hatta hukuki önlemler caydırıcılığı sebebiyle özellikle önem taşımaktadır.

Günümüzde özellikle başta İsveç, Hollanda, Danimarka, Finlandiya, Fransa ve Belçika gibi pek çok Avrupa Birliği ülkesinde mobbinge yönelik hukuki düzenleme yapılmış bulunmaktadır. Ancak Türkiye'de mobbingin tanımının yapıldığı bir hukuki düzenleme yoktur. Bunun yanında mobbing ile ilişkilendirilebilecek düzenlemeler 1982 Anayasası, ${ }^{22} 6098$ sayılı Türk Borçlar Kanunu, ${ }^{23} 4857$ sayılı İş Kanunu, ${ }^{24} 5237$ sayılı Türk Ceza Kanunu ${ }^{25}$ ve 6331 sayılı İş Sağlığı ve Güvenliği Kanunu ${ }^{26}$ gibi pozitif hukuk metinlerinde bulunmaktadır.

\subsection{Anayasa}

Mobbinge bakış açısı mobbingin hukuksal metinlerdeki durumunu da ortaya koymaktadır. Mobbingin pozitif hukuk kaynaklarında tanımlanmamış olması mobbingi önlemeye yönelik olarak kaynaklık sağlayacak hükümlerin bulunmadığı anlamına gelmemektedir. Özellikle 1982 Anayasası'nın birçok maddesi mobbing olgusunun gerçekleşmesini önleyecek içeriğe sahiptir. ${ }^{27}$ Anayasanın ilgili maddeleri;

- Her Türk vatandaşı bu Anayasadaki temel hak ve hürriyetlerden eşitlik ve sosyal adalet gereğince yararlanma, milli kültür, medeniyet ve hukuk düzeni içinde onurlu bir hayat sürdürme, maddi ve manevi varlığını bu yönde geliştirme hak ve yetkisine sahiptir (Başlangıç).

- Herkes, dil, ırk, renk, cinsiyet, siyasi düşünce, felsefi inanç, din, mezhep ve benzeri sebeplerle ayrım gözetilmeksizin kanun önünde eşittir. Kadınlar ve erkekler eşit haklara sahiptir. Devlet bu eşitliğin yaşam geçmesini sağlamakla yükümlüdür. Bu maksatla alınacak tedbirler eşitlik ilkesine aykırı olarak yorumlanamaz (Anayasa m.10)

- Herkes, kişiliğine bağlı, dokunulmaz, devredilmez, vazgeçilmez temel hak ve hürriyetlere sahiptir (Anayasa, m.12/I).

- Hiç kimse zorla çalıştırılamaz. Angarya yasaktır (Anayasa, m.12/I)

- Herkes, yaşama, maddi ve manevi varlığını koruma ve geliştirme hakkına sahiptir (Anayasa, m.17/I).

- Kimseye işkence ve eziyet yapılamaz; kimse insan haysiyetiyle bağdaşmayan bir cezaya veya muameleye tabi tutulamaz (Anayasa, m.17/III)

- $\quad$ Kişi hürriyeti ve güvenliği (Anayasa, m.19).

- Herkes özel hayatına ve aile hayatına saygı gösterilmesini isteme hakkına sahiptir. Özel hayatın ve aile hayatının gizliliğine dokunulamaz (Anayasa m.20).

- Herkes haberleşme hürriyetine sahiptir. Haberleşmenin gizliliği esastır (Anayasa m.22)

- Herkes, vicdani dini inanç ve kanaat hürriyetine sahiptir (Anayasa, m.24/I). Kimse ibadete, dini ayin ve törenlere katılmaya, dini inanç ve kanaatlerini açıklamaya zorlanamaz; dini inanç ve kanaatlerinden dolayı kınanamaz ve suçlanamaz (Anayasa, m.24/III).

- Herkes, düşünce ve kanaat hürriyetine sahiptir (Anayasa m.25/I).

- Her ne sebeple olursa olsun kimse, düşünce ve kanaatlerini açıklamaya zorlanamaz; düşünce kanaatleri sebebiyle kınanamaz ve suçlanamaz (Anayasa m.25/II).

- Çalışma herkesin hakkı ve ödevidir (Anayasa, m.49).

- Devlet...çalışma barışını sağlamak için gerekli tedbirleri alır (Anayasa, m.49/II).

- Kimse, yaşına, cinsiyeti ve gücüne uymayan işlerde çalıştırılamaz (Anayasa m.50).

- Küçükler ve kadınlar ile bedeni ve ruhi yetersizliği olanlar çalışma şartları bakımından özel olarak korunurlar (Anayasa m.50/II).

Sayılan bu hükümler Anayasa m.11 gereği yasama, yürütme ve yargı organlarını, idare makamlarını ve diğer kuruluş ve kişileri bağlamaktadır. Bu kapsamda Devlet, Anayasa'dan kaynaklanan bu ödevlerini yerine getirmek için, gerekli mevzuatı hazırlayıp, uygulamaya koymak, mevzuatın işlerliğini denetlemek ve aksaklık durumunda gerekli idari ve cezai yaptırımları uygulamakla yükümlüdür.

\footnotetext{
222709 Sayılı 1982 Anayasası, 18.10.1982, 17863

${ }^{23} 6098$ sayılı Türk Borçlar Kanunu, 11.1.2011, 27836

${ }^{24} 4857$ sayılı İş Kanunu, 10.06.2003, 25134

${ }^{25} 5237$ sayılı Türk Ceza Kanunu, 26.09.2004, 25611

${ }^{26} 6331$ sayılı İş Sağlığı ve Güvenliği Kanunu, 20.06.2012, 28339

${ }^{27}$ Demir, Şamil, “Mobbing Olgusunun Hukuki Değerlendirmesi”, Ankara Barosu Dergisi, 2009, 67/2, ss. 139-145, s. 139, Doğancı, Doğa

Ekrem; Çakrak, Recep, “ Hukuki Düzenlemeler Çerçevesinde Psikoloji Taciz (Mobbing) ve İspat Yükü, Kara Tahta, 2016, 6, 77-106, s.85
} 


\subsection{Iş Kanunu}

İ̧̧ Kanunu'nda mobbingle ilgili doğrudan doğruya bir düzenleme olmamakla birlikte İş Kanunu'nun işçiyi koruyucu yapısı, mobbing olarak nitelendirilebilecek kimi davranışlara karşı yetersizde olsa koruyucu bir yapı oluşturmaktadır. ${ }^{28}$

Türkiye'de mobbingle ilgili ilk yargısal karar Ankara 8. İş Mahkemesi tarafından 2006 yılında verilmiştir. illgili kararda, bir buçuk sene içinde beş kez yazılı savunması alınan ve haksız kınama cezasına uğradığı tespit edilen iş̧i 1000 tl manevi tazminata hak kazanmıştır. Kararda mobbing; "işyerinde çalışanlara üstleri, eşit düzey çalışanlar ya da astları tarafından sistematik biçimde uygulanan her tür kötü muamele, tehdit, şiddet, aşağılama" olarak tanımlanmıştır. Böylelikle mobbing kavramı ilk kez bu kararda ele alınmış, tanımı yapıımış ve hukuki açıdan değerlendirilmiştir. ${ }^{29}$

İ̧ Kanunu m.5'e göre, "iş ilişkilerinde dil, din, ırk, cinsiyet, siyasal düşünce, felsefi inanç ve benzeri sebeplere dayalı ayrım yapılamaz". Maddenin 6.fıkrasına göre; iş ilişkisinde veya sona ermesinde bu hükme aykırı davranılması durumunda iş̧̧i, dört aya kadar ücreti tutarında bir tazminattan başka yoksun bırakıldığı haklarını da talep edebilir. Söz konusu durumda işçinin ispat yükümlülüğü söz konusudur. Ancak işçinin bir ihlalin varlığı ihtimalini güçlü bir şekilde gösteren bir durumu ortaya koyması durumunda işveren böyle bir ihlalin mevcut olmadığını ispat etmekle yükümlüdür.

Söz konusu madde eşit davranma borcu olarak da anılmaktadır. Eşit davranma borcu en genel biçimde; işverenin haklı bir neden olmaksızın işyerinde çalışan işçilere farklı davranmamasıdır. Bir diğer değişle eşit durumdakilere eşit davranmasıdır. Bu borç temelini AY. m.10'dan almaktadır. Illgili maddeye göre; "herkes, dil, ırk, renk, cinsiyet, siyasi düşünce, felsefi inanç, din, mezhep ve benzeri sebeplerle ayrım gözetilmeksizin kanun önünde eşittir". ${ }^{30}$ Eşitlik ilkesi, işverenin işçiler arasında keyfi veya belirli nedenlere dayalı olarak ayrımcılık yapmasını yasaklamaktadır. ${ }^{31}$ issverenler yönetim hakkını kullanırken bu madde kapsamında işlemler yapmalıdırlar. Örneğin işin dağıtımında, ücretlerin belirlenmesinde, sosyal hakların ve ikramiyelerin dağıtımında bu borç ortaya çıkmaktadır. ${ }^{32}$

Eşitlik ilkesine aykırıı̆ın yaptırımı 4 aya kadar ücret tutarındaki ayrımcılık tazminatıdır. Ayrımcılık tazminatı ile diğer tazminat türleri arasındaki ilişki doktrinde tartışmalıdır. Örneğin iş güvencesi tazminatı ile birlikte ayrımcılık tazminatına hükmetmenin aynı suçtan birden fazla kez hukuki yaptırıma tabi tutulması olacağı görüşü olduğu gibi iki tazminatın farklı amaçları olduğu görüşünden hareketle aynı anda hükmedilebileceği görüşü de bulunmaktadır. ${ }^{33}$ Benzer şekilde kötü niyet tazminatı ile ayrımcılık tazminatının beraber istenebileceği görüşü de savunulmuştur. ${ }^{34}{ }^{35}$

İş Kanunu m.24/II/b’ye göre; “ Isşveren işçinin veya ailesi üyelerinden birinin şeref ve namusuna dokunacak şekilde sözler söyler, davranışlarda bulunursa veya işçiye cinsel tacizde bulunursa", ' $d$ ' bendine göre; "işşinin diğer bir iş̧̧iye veya üçüncü kişiler tarafından işyerinde cinsel tacize uğraması ve bu durumu işverene bildirmesine rağmen gerekli önlemler alınmazsa" işçi iş sözleşmesini sürenin bitiminden önce veya bildirim süresini beklemeksizin haklı nedenle feshedebilir. ${ }^{36}$

\footnotetext{
${ }^{28}$ Tınaz vd., Çalışma Psikolojisi ve Hukuki Boyutlarıyla İşyerinde Psikolojik Taciz (Mobbing), s.82

${ }^{29}$ Tınaz vd., Çalışma Psikolojisi ve Hukuki Boyutlarıyla İşyerinde Psikolojik Taciz (Mobbing), s.142

${ }^{30}$ İşveren bir başka işçiye bıyıklı bir şekilde çalışma noktasında izin verirken bir diğerine izin vermemesi eşit davranma ilkesine uymamaktadır (Yarg. 9. HD. 06/03/2003 E. 2002/15937 K. 2003/3176).

${ }^{31}$ Yıldız, Gaye Burcu, İşverenin Eşit Davranma Borcu, Ankara, 2008, s.65

${ }^{32}$ işverenin diğer iş̧̧ilerin ücretlerine zam yaptığı halde davacı işçinin ısrarına rağmen onun ücretine zam yapmaması sonucu davacının iş sözleşmesini feshetmesi haklı bir sebebe dayanmaktadır. Bu durumda ihbar tazminatının ödenmemesi yerinde olmakla birlikte kıdem tazminatııı ödenmesi gerekmektedir.(Yarg. 9. HD. 01/11/2004, E. 8671 K. 24558) İşverenin aynı nitelikte olan işe aldığı sendika üyesi emsal iş̧̧iye göre daha yüksek ücret ödemesi eşitlik ilkesine aykırı değildiri. Söz konusu işlemde farklı davranılması sözleşme serbestisi kapsamındadır (Yarg. 9. HD. 07/10/2013, E. 33127 K. 25090). Tüm işçilere seyyanen yapılan bir ücret zammından emekli olması planlanan iş̧̧ilerin yararlandırılmaması eşit davranma ilkesi ile bağdaşmaz (Yarg. 9. HD. 06/10/2003, E.3501 K. 16308).

${ }^{33}$ Limoncuoğlu, Alp, “iş̧ Hukuku Kapsamında Psikolojik Tacizin Değerlendirilmesi ve Mağdurların Kullanabilecekleri Haklar", Türkiye Barolar Birliği Dergisi, 2013, 105, s.70

${ }^{34}$ Limoncuoğlu, "İ̧̧ Hukuku Kapsamında Psikolojik Tacizin Değerlendirilmesi ve Mağdurların Kullanabilecekleri Haklar", s.70

${ }^{35}$ Aynı fesih sebebine bağlı olarak iki ayrı tazminata hükmedilebilmesi ancak kanunun açıkça belirttiği hallerde mümkündür. Kötü niyet tazminatı yanında ayrıca ayrımcılık tazminatına hükmedilemez (Yarg. 22. HD. E. 2012/29053 K. 2013/27095). Ancak bu durum beraberinde haksızlıkları da getirebilmektedir. Örneğin; eşitlik ilkesine aykırı olarak düşük ücret ödenmesi durumunda, işçi eksik ödenen ücret farkını isteyebilir. Bu karşılık ayrımcılık tazminatını isteyemez (Yarg. 9. HD. 22/04/2008, E. 13925 K. 9890).

${ }^{36}$ işe iade sonrası tekrar işe başlayan iş̧̧ daha önce çalıştı̆̆ı yerde çalıştııılmayıp, kapısı olmayan, içerisinde sadece bir masa ve hijyenik olmayan tuvalet bulunan, köpek kulübesine yakın bir yerde çalışmaya zorlanan kişi mobbing uygulaması ile karşılaşmış bulunup, işini kaybetmek korkusuyla belli bir süre burada çalışması süreklilik arz eden bu uygulamayı kabul ettiği anlamına gelmemektedir (Yarg. 9. HD. 05/04/2012, E. 2010/1911 K. 2012/11638). Banka avukatının 9 ay içinde 30 kez yer değiştirmek suretiyle görevlendirilmesinin hangi intiyaçtan kaynaklandığı ortaya konulmamıştır. Diğer çalışanlara da benzer şekilde davranıldığı iddia edilmekle birlikte kanıtlanamamıştır. Mobbing durumunda belli bir kişinin belli bir amaca yönelik olarak hedef alınması gerekir, işyerindeki haksız, kaba ve kııııı davranışların diğer çalışanlara da yapılması durumunda mobbingden söz edilemez (Yarg. 22. HD. 22/05/2014, E. 2013/11788 K. 2014/14008
} 
Şeref ve namusa dokunacak söz ve davranışlar konusunda ölçü koymak oldukça zordur. Çünkü söz konusu kavram çevreye ve zamana göre değişiklik göstermektedir. Bu sebeple her olayda, olayın özellikleri, tarafların karşılıklı durumları ve içinde bulundukları sosyal çevrede baskın düşünüş ve davranışlar göz önünde bulundurulmalıdır. ${ }^{37}$

İşverenin gerekli önlemleri almasından kasıt, olayın tekrar etmesini engellemek adına iş̧̧inin çalıştığı yeri değiştirmesi veya tacizcinin işine son verilmesi gibi işverenin çabasını gösteren davranışlardır. ${ }^{38}$

İ̧ Kanunu m.24/II/c'ye göre; işverenin işçiye veya ailesinden birisine sataşması, gözdağı vermesi, kanuna karşı davranışlara özendirmesi, kışkırtması, sürüklemesi veya hapsi gerektiren bir suç işlemesi şeref ve haysiyet kırıcı asılsız isnat veya ithamlarda bulunması işçi açısından haklı nedenle fesih nedenidir. Söz konusu durumların mobbing olarak adlandırılabilmesi kasıtlı ve sistematik nitelik sergilemiş olması gerekmektedir. Ancak söz konusu davranışlar psikolojik taciz davranışı olarak nitelendirilebilir. Bu sebeple bu davranışlarla karşılaşan iş̧̧iler haklı nedenle iş sözleşmelerini feshedebilirler.

Çokça karşılaşılmamakla birlikte iş̧̧iler işverenlerine veya kendilerinden hiyerarşik olarak üst konumundaki işveren vekillerine karşı mobbing yapması durumunda da işverenin haklı nedenle derhal fesih hakkı vardır. ilgili m.25'e göre; “ işçinin işverene yahut onun ailesi üyelerinden birine yahut işverenin başka işçisine sataşması...", "işçinin, işveren yahut bunların aile üyelerinden birinin şeref ve namusuna dokunacak sözler sarfetmesi veya davranışlarda bulunması, yahut işveren hakkında şeref ve haysiyet kırıcı asılsız ihbar ve isnatlarda bulunması", "işçinin yapmakla görevli bulunduğu görevleri kendisine hatırlatıldığı halde yapmamakta ısrar etmesi" durumunda işverenin haklı nedenle derhal fesih hakkı vardır.

İşveren çalışma koşullarında sürekli değişiklikler yaparak da mobbing yapabilir. ${ }^{39}$ iş Kanunu m.22'ye göre; işveren çalışma koşullarında esası ıir değişiklik yapacak olursa durumu işçiye yazııı olarak bildirmek zorundadır. İşçinin yazılı olarak kabul etmediği değişiklikler iş̧̧iyi bağlamamaktadır.

İşçinin haklı nedenle fesih hakkını altı işgünü içinde kullanması gerekmekle birlikte Yargıtay kararına göre psikolojik taciz bir süreç olup altı işgünlük sürenin burada uygulanması uygun değildir. Bir başka deyişle bu sürenin geçtiğinden söz edilemez. ${ }^{40}$

Mobbingi bir iş sağlığı ve güvenliği olgusu olarak ele aldığımızda İ̧ Kanunu'nun mülga 77.maddesi karşımıza çıkmaktadır. Maddeye göre; işverenler işyerinde isG'nin sağlanması için gerekli her türlü önlemi almak, araç ve gereçleri noksansız bulundurmak, işçiler de iSG konusunda alınan her türlü önleme uymakla yükümlüdürler. 2.fıkrasına göre iş güvenliği uygulamalarına uyulup uyulmadığını denetleme görevi işverenlere vermiştir. İlgili madde 6331 sayılı İş Sağlığı ve Güvenliği Kanunu'nun çıkmasıyla birlikte mülga konuma düşmüştür.

\subsection{Türk Borçlar Kanunu}

2011 yılında kabul edilen 6098 sayılı Türk Borçlar Kanunu'na(TBK) kadar 1926 tarihli 818 sayılı Borçlar Kanunu yürürlükte bulunmaktaydı. Seksen altı yılın sonunda yürürlükten kalkan kanunun yerine gelen TBK daha önce BK'da bulunmayan hükümleri getirmekle kalmamış iş Kanunlarında yer almayan hükümlere de yer vermiştir. Bunların başında çalışmamızın kapsamında bulunan işçinin kişiliğinin korunmasıyla ilgili m.417'de bulunmaktadır. ${ }^{41}$

Söz konusu maddeler ile işçinin sadakat borcunun karşılığı olan işverenin gözetme borcu düzenlenmiştir. İşverenin gözetme borcu; işçinin haklı menfaatlerini koruma ve gözetmeyi işçinin bu menfaatlerine zarar gelmesini önlemeyi içermektedir. ${ }^{42}$ Hem sadakat borcu hem de gözetme borcu geniş kapsamlı borçlardır.

Koruma ve gözetme borcu kapsamında iş sağlığı ve güvenliği önlemlerini alma borcu işverene, işçinin sadece fiziksel sağlığını değil ruhsal ve psikolojik sağlığını da koruma yükümlülüğü yüklemektedir. ${ }^{43}$

TBK m.417’ye göre; “işveren, hizmet ilişkisinde işçinin kişiliğini korumak ve saygı göstermek ve işyerinde dürüstlük ilkelerine uygun bir düzeni sağlamakla, özellikle işçilerin psikolojik ve cinsel tacize uğramamaları ve bu tür tacizlere uğramış olanların daha fazla zarar görmemeleri için gerekli önlemleri almakla yükümlüdür." (f.1) İşveren bu düzenleme kapsamında emir, talimat ve fiillerinin işçinin kişilik haklarına, şeref, haysiyet ve özel yaşamına, maddi ve manevi bütünlüğüne, onuruna, özel

\footnotetext{
${ }^{37}$ Narmanlıoğlu, Ünal, İş Hukuku: Ferdi İş iliş̧kileri I, Beta Yayınevi, İstanbul, 2014, s.425

${ }^{38}$ Şakar, Müjdat, Gerekçeli ve İçtihatlı İş Kanunu Yorumu, Parametre, Ankara, 2015, s.579

${ }^{39}$ Bilge, Selahattin Samet, "Mobbing Terimi ve Türk Hukuk Düzeninde İncelenmesi”, Ankara Üniversitesi Hukuk Fakültesi Dergisi, 2016, 65(4), 1245-1290, s.1269; Yarg. 9. HD. 15/10/2009, E. 2008/10408 K. 2009/16968

${ }^{40}$ Yarg. 9. HD. 4/11/2010 2008/37500 K. 2010/31544; Limoncuoğlu, Alp, “İşçinin İş Sözleşmesini Psikolojik Tacize Dayalı Olarak Haklı Nedenle Feshinde Hak Düşürücü Sürenin BaşlangıcI, DEÜHFD, 2013, 15, s.547-571

${ }^{41}$ M.417'ye ek olarak sözleşmenin geçersizliğinin etkisi(m.394), sadakat ve sır saklama borcu(m.396), işçinin işverene verdiği zarardan sorumluluğu(m.400), ücret türleri(m.401-405), temerrüdü(m.408), hizmet sözleşmesinde ibra(m.420), işveren belirli süreli iş sözleşmelerinin haksız feshi(m.430) maddeleri TBK'da bulunan ama daha önceki İş Kanun'larında yer almayan maddelerdir.

${ }^{42}$ Kaplan, Emine Tuncay, "Yeni Türk Borçlar Kanunu Hükümlerine Göre İş İlişkisinde İşçinin Kişilik Haklarının Korunması”, Sicil İş Hukuku Dergisi, sayı 24, 2011, 41

${ }^{43}$ Çelik, Nuri, İş Hukuku Dersleri, Beta Yayınevi, İstanbul, 2016, s.284, Narmanlıoğlu, İş Hukuku: Ferdi i̇ş illişkileri, s.321
} 
yaşamına, ahlaki değerlerine, düşünce, ifade ve sendikal özgürlüklerine aykırı olmamalıdır. ${ }^{44}$ Aynı maddenin 2. fıkrasına göre "Işveren, işyerinde iş sağlığı ve güvenliğinin sağlanması için gerekli her türlü önlemi almak, araç ve gereçleri noksansız bulundurmak; işçiler de iş sağlığı ve güvenliği konusunda alınan her türlü önleme uymakla yükümlüdür." İşveren bu borcu kapsamında, işçiyi işletme tehlikelerine karşı koruma, işçiye uygun ve sıhhi çalışma yeri verme borcu altına girmektedir. ${ }^{45} \mathrm{Bu}$ düzenleme ile psikolojik taciz tanımlanmamış olmakla birlikte pozitif olarak düzenlenmiştir. ${ }^{46}$

İşveren işçiyi koruma borcu kapsamında işçini bedensel bütünlüğünü koruyucu tüm tedbirleri alması, maddi ve manevi değerlerine saygı göstermesi, işçinin özel bilgilerinin korunması ve başkalarıyla paylaşılmamasını, şeref ve onurunun, kişisel ve mesleki saygınlığının, ahlaki değerlerinin, özel yaşam alanının, genel olarak özgürlüğünün de korunmasını içermektedir. ${ }^{47}$

İşveren bu sorumluluğunu yerine getirmek üzere tarafsız bir merci oluşturmalı, işçileri mobbing konusunda bilgilendirmesi, bilinçlendirmesi, memnuniyet anketleri yoluyla psikolojik taciz ihtimalini değerlendirmesi veya psikolojik tacizi ortaya çıkarması ve bu sonuçlara göre hemen önlem alması gerekmektedir. ${ }^{48}$

Psikolojik ve cinsel taciz sebebiyle işçilerin sağlığı ve vücut bütünlüğü bozulabilmektedir. ${ }^{49}$ Bu sebeple psikolojik ve cinsel taciz iş sağlığı ve güvenliği kapsamında değerlendirilmelidir.

Psikolojik taciz mağduru TBK m.49'a göre maddi tazminat isteyebilir. Buna ek olarak, yaşadığı depresyon sebebiyle yaptığı tedavi harcamaları, iktisadi geleceğinin sarsılmasına ilişkin zararlar, hakkında çıkan asılsız dedikodular sebebiyle iş bulamaması sonucu uğradığı zararlar, ayrımcılık sebebiyle ücret artışı yapıımaması gibi zararlarının tazminini isteyebilir. ${ }^{50}$

Mobbing sonucu üzüntü, kaygı, utanç duyan, depresyona giren kişinin TBK m.58 gereği manevi tazminat isteyebilmesi mümkündür. ${ }^{51}$

\subsection{Türk Ceza Kanunu}

Türk Ceza Kanunu'nda psikolojik tacizle ilgili açık bir yasal düzenleme bulunmamakla birlikte psikolojik taciz sürecinde mağdurun karşı karşıya kaldığı davranışları düzenleyen hükümler bulunmaktadır. Bunlar; kasten yaralama(TCK, m.86), taksirle yaralama (TCK, m.89), hakaret (TCK, m.125), intihara yönlendirmedir (TCK, m.84).

TCK m.122'ye göre kişiler arasında dil, din, ırk, renk, cinsiyet, siyasi düşünce, felsefi inanç, din, mezhep vb. sebeplerle ayrım yaparak kişinin temel hak ve özgürlüklerine zarar veren kimseye 1 yıl hapis veya adli para cezası verilebilecektir.

TCK 'nın 94. Maddesine göre; bir kişiye karşı insan onuruyla bağdaşmayan ve bedensel veya ruhsal yönden acı çekmesine, algılama veya irade yeteneğinin etkilenmesine aşağılanmasına yol açacak davranışları gerçekleştiren kamu görevlisi hakkında 3 yıldan 12 yıla kadar hapis cezasına hükmolunur.

TCK'nın 96.maddesine göre; bir kimsenin eziyet çekmesine yol açacak davranışları gerçekleştiren kişi hakkında iki yıldan beş yıla kadar hapis cezası hükmolunur.

TCK' nın 123. Maddesine göre, sırf huzur ve sükununu bozmak maksadıyla bir kimseye ısrarla telefon edilmesi, gürültü yapılması ya da aynı maksatla hukuka aykırı başka bir davranışta bulunulması halinde, mağdurun şikayeti üzerine faile üç aydan bir yıla kadar hapis cezası verilir.

TCK' nın 125. Maddesine göre; Bir kimseye onur, şeref ve saygınlığını rencide edebilecek nitelikte somut bir fiil veya olgu isnat eden veya sövmek suretiyle bir kimsenin onur, şeref ve saygınlığına saldıran kişi, üç aydan iki yıla kadar hapis veya adlî para cezası ile cezalandırıır. Mağdurun gıyabında hakaretin cezalandırılabilmesi için fiilin en az üç kişi huzurunda işlenmesi gerekir. Fiilin, mağduru muhatap alan sesli, yazılı veya görüntülü bir iletiyle işlenmesi hâlinde, yukarıdaki fıkrada belirtilen cezaya hükmolunur. Hakaret suçunun;

a) Kamu görevlisine karşı görevinden dolayı,

\footnotetext{
${ }^{44}$ Korkmaz, Fahrettin; Alp, Nihat Seyhun, Bireysel İ̧̧ Hukuku, Seçkin Yayınevi, Ankara, 2014, s.169

${ }^{45}$ Yavuz, Cevdet, Borçlar Hukuku Dersleri (Özel Hükümler), Beta Yayınevi, Ankara, 2013, s.481

${ }^{46}$ Çelik, İş Hukuku Dersleri, s.285; Ünal, Canan, “ Karşılaştırmalı Hukuk Işığında İşyerinde Psikolojik Tacizin İşverenin İşçinin Kişiliğini Koruma ve Eşit Davranma Borcu Kapsamında Değerlendirilmesi, Legal IHD, 2013, 37, s.38

${ }^{47}$ Çelik, İş Hukuku Dersleri, s.206; Süzek, 2013, s. 406

${ }^{48}$ Çelik, İş Hukuku Dersleri, s.287

${ }^{49}$ Sevimli, K. Ahmet, "Türk Borçlar Kanunu m.417 ve İş Sağlığı ve Güvenliği Işığında Genel Olarak İş̧inin Kişiliğinin Korunması”, Çalışma ve Toplum Dergisi, sayı 36, 2013, s. 125

${ }^{50}$ Bilgili, Abbas, İş Hukuku Açısından Mobbing, Karahan Kitapevi, Adana, 2012, s.37

${ }^{51}$ Doğancı, Çakrak, " Hukuki Düzenlemeler Çerçevesinde Psikoloji Taciz (Mobbing) ve İspat Yükü, s.87; Söz konusu tazminat miktarı belirlenirken, eylemlerin ağılığı ve bu eylemlerin yapılmasında davacının kısmi kusuru da dikkate alınmalıdır (Yarg. 7. HD. 06/03/2014 E. 2013/20568 K. 2014/5379).
} 
b) Dinî, siyasî, sosyal, felsefi inanç, düşünce ve kanaatlerini açıklamasından, değiştirmesinden, yaymaya çalışmasından, mensup olduğu dinin emir ve yasaklarına uygun davranmasından dolayı,

c) Kişinin mensup bulunduğu dine göre kutsal sayılan değerlerden bahisle işlenmesi halinde cezanın alt sınırı bir yıldan az olamaz. Ceza, hakaretin alenen işlenmesi halinde altıda biri, basın ve yayın yoluyla işlenmesi halinde üçte biri oranında artııılır. Suç, kurul hâlinde çalışan kamu görevlilerine görevlerinden dolayı hakaret edilmesi hâlinde, kurulu oluşturan üyelere karşı işlenmiş sayılır, denilmektedir.

Yukarıda sıralanan düzenlemelerin yeterliliği konusunda doktrinde tartışmalar söz konusudur. Düzenlemelerin yetersizliğini "Suçta ve Cezada Kanunilik" düşüncesine dayandıran bir görüşe göre psikolojik tacizin Kanunda açıkça tanımlanması gerekmektedir. ${ }^{52}$ Diğer bir görüşe göre ceza hukuku açısından mevcut düzenlemeler yeterlidir ve ayrıca bir düzenlemeye gerek yoktur. ${ }^{53}$ Kanaatimizce Ceza Hukuku'ndaki düzenlemeler yeterli olmakla birlikte doğrudan mobbingi ele alan bir düzenlemenin yapılması ve bir suç tipi olarak tanımlanması mobbingle mücadele açısından daha etkili olacaktır.

\subsection{Türk Medeni Kanunu}

Medeni Kanunun 2.maddesine göre herkes haklarını kullanırken ve borçlarını yerine getirirken dürüstlük kurallarına uymak zorundadır. Bu noktada işyerinde var olan birtakım haklar kötüye kullanılırsa yani psikolojik taciz amacıyla kullanırsa söz konusu maddeye aykırılık teşkil edecektir.

Medeni Kanunun 23.maddesine göre "kimse, hak ve fiil ehliyetlerinden kısmen de olsa vazgeçemez. Kimse özgürlüklerinden vazgeçemez veya onları hukuka ya da ahlaka aykırı olarak sınırlayamaz."

Medeni Kanunun 24.maddesine göre "hukuka aykırı olarak kişilik hakkına saldıılan kimse, hakimden saldırıda bulunanlara karşı korunmasını isteyebilir."

Medeni Kanunun 25.maddesine göre; "Davacı, hakimden saldırı tehlikesinin önlenmesini, sürmekte olan saldırıya son verilmesini, sona ermiş olsa bile etkileri devam eden saldırının hukuka aykııılı̆ının tespitini isteyebilir", "Davacının maddi ve manevi tazminat istemleri ile hukuka aykırı saldırı dolayısıyla elde edilmiş olan kazancın vekaletsiz iş görme hükümlerine göre kendisine verilmesine ilişkin istemde bulunma hakkı saklıdır.", "Manevi tazminat istemi, karşı tarafça kabul edilmiş olmadıkça devredilemez; miras bırakan tarafından ileri sürülmüş olmadıkça mirasçılara geçmez."

Psikolojik taciz henüz gerçekleşmemekle birlikte işçinin psikolojik tacize maruz kalacağı hususunda ciddi emareler ve endişeler söz konusuysa saldırının önlenmesi davası açılabilir. İşçi, psikolojik taciz başlamış ve devam etmekteyse saldırıya son verme davası açabilir. Psikolojik taciz sona ermiş ancak etkileri hala devam ediyorsa da tespit davası açılabilir. Buna ek olarak, düzeltmenin veya kararın üçüncü kişilere bildirilmesi ya da yayımlanması isteminde bulunabilir. Ek olarak maddi ve manevi tazminat talebinde bulunabilir. ${ }^{54}$

Söz konusu davalar psikolojik taciz işveren tarafından yapıldıysa işverene, işçiler tarafından yapıldıysa işçilere açılabileceği gibi buna göz yuman işverene de açılabilir. ${ }^{55}$

Medeni Kanunun 26.maddesine göre; “Adının kullanılması çekişmeli olan kişi, hakkının tespitini dava edebilir.", "Adı haksız olarak kullanılan kişi buna son verilmesini; haksız kullanan kusurlu ise ayrıca maddi zararının giderilmesini ve uğradığı haksızlığın niteliği gerektiriyorsa manevi tazminat ödenmesini isteyebilir."

\section{6. İ̧̧ Sağlığı ve Güvenliği Kanunu}

İ̧ Sağlığı ve Güvenliği Kanunu m.3'de işverenin, çalışanların işle ilgili sağlık ve güvenliği sağlamayla ilgili genel yükümlülüğü düzenlenmiştir. Madde 4'te ise "mesleki risklerin önlenmesi, eğitim ve bilgi verilmesi dahil her türlü tedbirin alınması" düzenlenmiş olup işverene oldukça geniş çaplı olarak görev yüklenmiştir. Buradaki "her türlü tedbirin alınması" tabiri kapsamında işveren sadece Kanun ile düzenlenen sorumluluklarını yerine getirmekle kalmayacak. Buna ek olarak ekonomik ve teknolojik gelişmelerin gerekli gördüğü her türlü önlemi almakla yükümlü olacaktır. ${ }^{56}$

iSGK m.13'de yer verilen çalışmaktan kaçınma hakkı 4857 sayılı Kanun döneminde m.83'de yer almaktaydı. Her iki yasa da temelini 155 sayılı ío sözleşmesi m.13’ten almaktadır. Ilgili maddeye göre, sağlığı ve hayatı için ciddi ve yakın tehlike

\footnotetext{
52 ilhan, Ümit, "İşyerinde Psikolojik Tacizin (Mobbing) Tarihsel Arka Planı ve Türk Hukuk Sistemindeki Yeri”, Ege Akademik Bakış, 2010, 10(4), 1175-1186

${ }^{53}$ Erdem, Mustafa Ruhan; Parlak, Benay, "Ceza Hukuku Boyutuyla Mobbing”, Türkiye Barolar Birliği Dergisi, 2010, 88, 261-286

${ }^{54}$ Çelik, İş Hukuku Dersleri, s.288; Centel, Tankut, "Türk Borçlar Kanunu'nda Genel Olarak İşçinin Kişiliğinin Korunması", Sicil ïHD, 2011, Aralık, s.15, Sümer, Haluk Hadi, İş Hukuku Uygulamaları, Seçkin Yayınevi, Ankara, 2016, s.278

55 Doğancı, Çakrak, " Hukuki Düzenlemeler Çerçevesinde Psikoloji Taciz (Mobbing) ve İspat Yükü, s.86

${ }^{56}$ Süzek, İş Hukuku, s.863, Baysal, Mustafa, Çözümlerle İş Kanunu Sorunları, Seçkin Yayınevi, Ankara, 2014, s.261
} 
nedeniyle, haklı bir gerekçeyle, işinden uzaklaşan bir iş̧̧inin, işinden uzaklaşması nedeniyle olabilecek uygunsuz sonuçlara karşı korunması gerekmektedir.

iSGK m.13 uyarınca ciddi ve yakın tehlike ile karşı karşıya kalan çalışanlar, işyerinde isG kurulu varlığında kurula, kurul bulunmuyorsa işverene başvurarak durumun sağlanması ile gerekli önlemlerin alınmasına karar verilmesini talep edebilir. Kurul acilen toplanarak kararını verir ve durumu bir tutanakla tespit eder. Karar, başvuruda bulunan çalışana ve çalışan temsilcisine yazılı olarak bildirilir. Kurulun veya işverenin çalışanın talebi yönünde karar vermesi halinde çalışan, gerekli önlemler alınıncaya kadar çalışmaktan kaçınabilir.

Söz konusu maddeyle verilmiş olan çalışmaktan kaçınma hakkı mobbing mağduru tarafından kullanılabilir. Ancak karşı karşıya olunan mobbingin iş̧̧inin işini görmesi durumunda yakın ve ciddi bir tehlike oluşturması gerekmektedir. Bu durumda iş̧̧i çalışmaktan kaçınabilecektir. ${ }^{57}$

iSGK m.13/2 uyarınca, çalışanların çalışmaktan kaçındığı dönemdeki ücreti ile yasalardan ve iş sözleşmesinden doğan hakları saklıdır. Ancak çalışmaktan kaçınmaya sebep olan yakın ve ciddi tehlikenin ortadan kalktığı veya kontrol altına alındığı hallerde işçinin çalışmaktan kaçınmaya devam etmesi durumunda ücret hakkı saklı kalmayacaktır. Hatta dürüstlük kurallarına aykırılık oluşturması durumunda işveren tarafından haklı nedenle derhal fesih hakkı kullanılabilecektir.

Işveren yukarıda sayılan durumlardaki sorumluluğunun niteliği doktrinde tartışmalıdır. Bir görüşe göre işverenin hukuki sorumluluğu kusursuz sorumluluk iken bir diğer görüşe göre ise işverenin hukuki sorumluluğu kusur sorumluluğudur.

Türk Borçlar Hukuku sisteminde kusur sorumluluğu genel sorumluluk prensibiyken kusursuz sorumluluk istisnaidir. Diğer bir ifadeyle, kusursuz sorumluluk esasına dayanabilmek için bu halin yasada açıkça düzenlenmesi gerekmektedir. Kusuru bulunmadığı halde doğan zarardan sorumlu tutulmaya kusursuz sorumluluk adı verilmektedir. ${ }^{58}$

Kusursuz sorumluluk hallerinde sorumluluğuna hükmedilen kişi çoğu kez kendi davranışı değil, başkalarının davranışı sebebiyle sorumlu tutulmaktadır. Bu durumlarda zararı veren kişi ile zarara sebep olan kişi aynı kişi olmayabilir. Bu sebeple kusursuz sorumluluk kavramına ayrıca sebep sorumluluğu ismi verilmektedir. ${ }^{59}$

Öğreti de ve eski Yargıtay kararlarında kusursuz sorumluluk görüşü ağırlık taşımaktadır. ${ }^{60}$ Ancak Yargıtay yeni kararlarında bu görüşünü değiştirmiş ve kusur sorumluluğunun esas alınması gerektiğini hükme bağlamıştır. ${ }^{61}$

TBK'da hukuka aykırı eylemin sorumluluk doğurması için kasten veya ihmal ile işlenmesi öngörülmüştür. Bir başka ifadeyle, haksız eyleme dayanan kusurun giderilmesi borcu için kusur kurucu öğedir. Haksız bir fiil ile bir başkasına zarar vere kimse, ancak kusurluysa bu zararı tazmin ile yükümlüdür (TBK, m.49/1, BK, m.41/1).

TBK m.112'ye göre "Borç hiç veya gereği gibi ifa edilmezse borçlu, kendisine hiçbir kusurun yüklenemeyeceğini ispat etmedikçe, alacaklının bundan doğan zararını gidermekle yükümlüdür."

İşverenin iş kazasından sorumlu tutulabilmesi için benzer işe sahip, dikkatli, makul ve sorumluluk sahibi bir işverenin davranış şeklini göstermesi beklenmektedir. Bu objektif davranışları sergilememeleri durumunda ise kusur sorumluluğu devreye girmektedir (Süzek, 2013: 414).

İşverenin kusurunun söz konusu olabilmesi için, işyeri koşullarından kaynaklanan tehlike ile ortaya çıkan zarar arasında nedensellik bağının bulunması gerekmektedir. Nedensellik bağı, mücbir sebep, zarar görenin veya üçüncü kişinin ağır kusuru nedeniyle kesilebilir. Bu durumda işverenin sorumluluğuna gidilemez. ${ }^{62}$

6331 sayılı İ̧ Sağlığı ve Güvenliği Kanunu ile birlikte proaktif bir yaklaşım benimsenmiş bulunup en önemli aşamalardan bir tanesi risk değerlendirmesidir. Risk değerlendirmesi; işyerinde var olan veya dışarıdan gelebilecek tehlikelerin belirlenmesi,

\footnotetext{
${ }^{57}$ Arslan Ertürk, Arzu, “iş Hukuku Boyutuyla Türkiye’de Psikolojik Taciz (Mobbing) ve Dünya'dan Örnekler”, Prof. Dr. Ali Rıza Okur’a Armağan, Marmara Üniversitesi Hukuk Fakültesi Hukuk Araştırmaları Dergisi, İstanbul, 2014, 20(1), s.308-309

${ }^{58}$ Kılıçoğlu, Mustafa, Borçlar Hukuku, Turhan Kitapevi, Ankara, 2014, s.318

${ }^{59}$ Akıncı, Şahin, Borçlar Hukuku Bilgisi, Sayram Yayınları, Konya, 2006, s. 158

${ }^{60}$ Yarg. 21. HD. 23/01/1996 E. 7235 K. 122; YHGK, 26/06/1981 E. 9-1949 K. 535

${ }^{61}$ "Bir iş kazasından işverenin sorumlu olması için, işverenin iş güvenliği önlemlerini alma ve özen gösterme yükümlülügüne aykırı davranışı veya ihmal göstermesi sonucu kaza meydana gelmiş olmalıdır" (YGHGK 03/02/2010, E.21-36 K. 67). 15 yaşında birini ağır ve tehlikeli işte çalıştırmak bizatihi kusur durumunu oluşturur (Yarg. 10. HD. 09/03/1981, E. 648 K. 1270). Düzenli bakımı yapılmayan 15 yıllık araçla işçisini göreve gönderen işverenin yükümlülüklerini tam olarak yerine getirdiğinden söz edilemez (Yarg. 21. HD. 07/02/2006, E. 2005/13299 K.2006/810)

${ }^{62}$ YHGK, 20.03.2013, E. 2012/21-1121, K. 2013/386
} 
tehlikelerin riske dönüşmesine yol açan faktörler ile tehlikelerden kaynaklanan risklerin analiz edilerek derecelendirilmesi ve kontrol tedbirlerinin kararlaştırıması amacıyla yapılması gerekli çalışmalardır. ${ }^{63}$

İşverenler çalışma ortamının ve çalışanların sağlık ve güvenliklerini sağlamak, devam ettirmek ve geliştirmek amacıyla iSG yönünden risk değerlendirmesi yapmak/yaptırmak zorundadırlar (iSGK.m.10; RiSKYÖN.m.5). İşverenin risk değerlendirmesi yaparken/yaptıırken; belirli risklerden etkilenecek olan çalışanların durumları, kullanılacak iş ekipmanları, kimyasal madde ve hazır müstahzarların seçimleri, işyerinin tertip ve düzeni ve özel olarak korunması gereken genç, yaşlı, engelli, gebe ve emzikli kadın çalışanlar gibi grupların durumlarını dikkate alması zorunludur (isGK.m.10).

İşverenin, risk değerlendirmesi yapmak/yaptırmak yükümlülüğünü yerine getirmiş olması, işyerinde isG'ni sağlama yükümlülüğünü ortadan kaldırmaz. Ayrıca işveren risk değerlendirmesi çalışmalarında görevlendirilen kişi ya da kişilere konu ile ilgili tüm bilgi ve belgeyi vermekle yükümlüdür (RiSKYÖN.m.5).

Türkiye pozitif hukukunda düzenlenmiş risk değerlendirme yönteminde fiziksel ve biyolojik etmenler ayrıntılı olarak değerlendirilmekle birlikte, psikolojik risk faktörleri göz ardı edilmektedir. ${ }^{64}$

Bu kapsamda mobbingin bir iş sağlığı ve güvenliği problemi olarak ele alınması ve risk değerlendirmesinde psiko-sosyal faktörlerin de incelenmesi gerekmektedir.

\subsection{Devlet Memurları Kanunu}

657 sayılı Devlet Memurları Kanunu'nda açıkça psikolojik tacize yer verilmemiş olmakla birlikte amirin maiyetindeki memurlara eşit davranma borcu düzenlenmiştir. ilgili 10.maddeye göre; “...Amir maiyetindeki memurlara hakkaniyet ve eşitlik içinde davranır. Amirlik yetkisini kanun, tüzük ve yönetmeliklerde belirtilen esaslar içinde kullanır." ${ }^{65}$

Devlet Memurları Kanunu m.8'de davranış ve işbirliği başlı̆ı altında şu düzenlemeye yer verilmiştir; "Devlet memurları, resmi sıfatlarının gerektirdiği itibar ve güvene layık olduklarını hizmet içindeki ve dışındaki davranışlarıyla göstermek zorundadırlar.", "Devlet memurlarının işbirliği içinde çalışmaları esastır." Madde gerekçesinde ayrıntılı bir şekilde memurlar arasındaki ilişkilerde dikkat edilmesi gereken unsurlar belirlenmiştir. Buna göre; devlet memurları hizmet arkadaşlarıyla münasebetlerinde memurların gerektirdiği terbiye, nezaket, ağır başlıık, sevgi, saygı, itibar ve iş birliği unsurlarına dikkat etme sorumluluğundadır.

Söz konusu düzenlemeler kapsamında dava açıldığında idarenin idare hukuku kapsamında sorumluluğu söz konusudur. Bu noktada Anayasa m.125/son'a göre, "idare, kendi eylem ve işlemlerinden doğan zararları ödemekle yükümlüdür". Anayasa m.40/son'a göre, " Kişinin, resmi görevliler tarafından vaki haksız işlemler sonucu uğradığı zarar da, kanuna göre, Devletçe tazmin edilir. Devletin sorumlu olan ilgili görevliye rücu hakkı saklıdır". Anayasa 129/5'e göre ise, " memurlar ve diğer kamu görevlilerinin yetkilerini davaları, kendilerine rücu edilmek kaydıyla ve kanunun gösterdiği şekil ve şartlara uygun olarak, ancak idare aleyhine açılabilir". ${ }^{66}$

\subsection{Gözden Geçirilmiş Avrupa Sosyal Şartı}

22 Mart 2007 tarihinde Türkiye tarafından onaylanan Avrupa Sosyal Şartının 26.maddesi onurlu çalışma hakkı ile ilgilidir. Buna göre;

“Akit Taraflar, tüm çalışanların onurlu çalışma haklarının etkili bir biçimde kullanılmasını sağlamak amacıyla işverenlerin ve çalışanların örgütlerine danışarak

1- Çalışanların işyerinde ya da işle bağlantılı cinsel taciz konusunda bilinçlenmesi, bilgilenmesi ve bunun engellenmesini desteklemeyi ve çalışanları bu tür davranışlardan korumaya yönelik tüm önlemleri almayı;

\footnotetext{
${ }^{63}$ Binbir, Sinan, İş Sağlığı ve Güvenliği Kanunuyla Birlikte Yargı Kararları, Açıklama ve Örneklerle İş Kanunu, Yaklaşım Yayınları, İstanbul, 2012, s.510

${ }^{64}$ Şahin, Serenay, "Yeni Bir Yaklaşım: İş Sağlığı ve Güvenliği'nde Mobbing Faktörünün Önemi ve Etkisi”, The Journal of Academic Social Science, 2015, 3(9), 489-505, s.493

${ }^{65}$ Atandığı günden beri manevi yapısının olumsuz etkileyecek derecede mobbinge maruz kalan öğretim üyesine manevi tazminat ödenmesine ilişkin ilk derece kararı Danıştay tarafından onanmıştır. Dan. 8. D., E. 2008/10606 K. 212/1736

${ }^{66}$ Bilgili, İş Hukukunda Mobbing, s.15, Kamu görevlilerinin yetkilerini kullanırken işledikleri kasıtlardan ve kusurlardan doğan tazminat davalarında kamu görevlilerinin aleyhine değil ancak kamu idaresi aleyhine dava açılabileceğinin kabulü gerekir (Yarg. 4. HD. E. 2010/11459 K. 2011/13283). Ancak Yargıtay Hukuk Genel Kurulu önüne gelen bir uyuşmazlıkta devrim niteliğinde bir karar alınmış olup davaya konu olan eylemlerin hizmet kusuru mu yoksa hizmetten ayrılabilen kişisel kusur mu olduğu incelenmiştir. Buna göre Anayasa m.129/5'e göre memurların ve diğer kamu görevlilerinin yetkilerini kullanırken meydana gelen zararlara ilişkin davaların idare aleyhine dava açılabilmesinin, eylemin hizmet kusurundan kaynaklanmış olması koşuluna bağlı olduğu kararı verilmiştir (Yarg. HGK. 11/11/2015, E. 2014/4-110 K. 2015/2600).
} 
2- Çalışanların birey olarak işyerinde ve işle bağlantılı olarak maruz kaldıkları kınanılacak ya da açıkça olumsuz ya da suç oluşturan, yinelenen eylemler konusunda bilinçlenmesi, bilgilenmesi ve bunların engellenmesini desteklemeyi ve çalışanları bu tür davranışlardan korumaya yönelik tüm uygun önlemleri almayı taahhüt eder."

Bu düzenleme ile sözleşmeyi imzalayan devletlerin cinsel taciz ve psikolojik taciz konusunda bilinçlendirilmesi, bunun engellenmesi ve işçilerin korunması için amaçları güdülmüş bulunup devletler bu konuda sorumluluk altına girmiştir.

\section{9. İşyerinde Psikolojik Tacizin (Mobbing) Önlenmesi Genelgesi}

Mobbing ile ilgili olarak atılmış en önemli adımlardan bir tanesi İşyerinde Psikolojik Tacizin Önlenmesi Genelgesi'dir. Genelgeye göre;

"Kamu kurum ve kuruluşları ile özel sektör işyerlerinde gerçekleşen psikolojik taciz, çalışanların itibarını ve onurunu zedelemekte, verimliliğini azaltmakta ve sağlığını kaybetmesine neden olarak çalışma hayatını olumsuz etkilemektedir. Kasıtlı ve sistematik olarak belirli bir süre çalışanın aşağılanması, küçümsenmesi, dışlanması, kişiliğinin ve saygınlığının zedelenmesi, kötü muameleye tabi tutulması, yıldırılması ve benzeri şekillerde ortaya çıkan psikolojik tacizin önlenmesi gerek iş sağlığı ve güvenliği gerekse çalışma barışının geliştirilmesi açısından çok önemlidir. Bu doğrultuda, çalışanların psikolojik tacizden korunması amacıyla aşağıdaki tedbirlerin alınması uygun görülmüştür.

1- İşyerinde psikolojik tacizle mücadele öncelikle işverenin sorumluluğunda olup işverenler çalışanların tacize maruz kalmamaları için gerekli bütün önlemleri alacaktır.

2- Bütün çalışanlar psikolojik taciz olarak değerlendirilebilecek her türlü eylem ve davranışlardan uzak duracaklardır.

3- Toplu iş sözleşmelerinde işyerinde psikolojik taciz vakalarının yaşanmaması için önleyici nitelikte hükümler konulmasına özen gösterilecektir.

4- Psikolojik tacizle mücadeleyi güçlendirmek üzere Çalışma ve Sosyal Güvenlik Iletişim Merkezi, ALO 170 üzerinden psikologlar vasıtasıyla çalışanlara yardım ve destek sağlanacaktır.

5- Çalışanların uğradığı psikolojik taciz olaylarını izlemek, değerlendirmek ve önleyici politikalar üretmek üzere Çalışma ve Sosyal Güvenlik Bakanlığı büntesinde Devlet Personel Başkanlığı, sivil toplum kuruluşları ve ilgili tarafların katılımıyla "Psikolojik Tacizle Mücadele Kurulu" kurulacaktır.

6- Denetim elemanları, psikolojik taciz şikayetlerini titizlikle inceleyip en kısa sürede sonuçlandıracaktır.

7- Psikolojik taciz iddialarıyla ilgili yürütülen iş ve işlemlerde kişilerin özel yaşamlarının korunmasına azami özen gösterilecektir.

8- Çalışma ve Sosyal Güvenlik Bakanlığı, Devlet Personel Başkanlığı ve sosyal taraflar, işyerlerinde psikolojik tacize yönelik farkındalık yaratmak amacıyla eğitim ve bilgilendirme toplantıları ile seminerler düzenleyeceklerdir."

\subsection{Yargitay Kararları}

Bu bölümde mobbing doktrinini ve hukuksal süreçleri etkileme yeteneği olduğu düşünülen Yargıtay kararlarına yer verilmiştir. Yargıtay kararları uygulamada karşılaşılan ispat sorunlarının giderilmesi adına yardımcı olacaktır

Yargıtay 9. HD. kararına göre; Davacı amiri tarafından cinsel ilişki teklif edildiğini kabul edilmeyince performans notunun düşürüldüğünü, işyerinde olayın duyulması ile birlikte bunalıma girerek çalışamaz duruma gelince iş sözleşmesini sona erdirmiştir. Söz konusu davada davacının kendi iffetini herhangi bir sebep yokken ortaya koyması yaşamın olağan akışına aykırıdır. Taciz olayları olaylarının etki ve sonuçları temadi etmekte olup sonuçları itibariyle bir nevi mobbinge dönüşen eylemler karşısında 6 günlük hak düşürücü sürede fesih hakkının kullanılmadığından bahsedilemez. ${ }^{67}$

Bu Yargıtay kararına göre 6 günlük hak düşürücü süre mobbinge uygulanmamalıdır. Çünkü cinsel taciz zaman içinde bir nevi mobbing haline gelmiştir ve mobbing bir davranıştan çok bir süreci ifade etmektedir.

Yargıtay 22. HD kararı ile mobbingin diğer kavramlarla arasındaki ilişki ve farklılıklara açıklık getirilmeye çalışılmıştır. İlgili karara göre; "mobbingi; stres, tükenmişlik sendromu, işyeri kabalığı, iş tatminsizliği ya da doyumsuzluğu gibi olgulardan ayıran husus, belli kişinin belli bir amaca yönelik olarak hedef alınması, yapılan haksızlığın sürekli, sistematik ve sık oluşudur." 68

Yargıtay 22. HD.'nin bir oldukça önemli bir kararına göre; Davacının uyarı, itham ve kırıcı üsluplara, baskılara maruz kaldığı, sorun çıkaran, uyumsuz, sevilmeyen biri olarak suçlandığı ve başka işçilerin yapması gereken işlerin sık sık davacıya verildiği, düşük performans notu verildiği, diğer çalışanlardan soyutlandığı, hakarete maruz kaldığı, yaşamış olduğu olumsuzlukları amirine ilettiği halde sorunlarına çözüm getirilmediği ve kendisinde kusur bulunduğu, anksiyete bozukluğu çektiği ve sağlık sorunlarıyla uğraştığı konusundaki yazıda kişinin samimi, tutarlı ve bütünlüklü olduğu dosya içeriğinden anlaşılmıştır.

\footnotetext{
${ }^{67}$ Yarg. 9. HD. E.2008/37500 K. 2010/31544

${ }^{68}$ Yarg. 22. HD. 22/05/2014 E. 2013/11788 K. 2014/14008, Bilgili, Türk İş Hukukunda Mobbing, s.91
} 
Mobbingin varlığı için kişilik haklarının ağır şekilde ihlaline gerek olmadığı, kişilik haklarına yönelik haksızlığın yeterli olduğu, ayrıca mobbing davalarında şüpheden uzak kesin deliller aranmayacağı; davacı iş̧̧inin, kendisine işyerinde mobbing uygulandığına dair kuşku uyandıracak olguların ileri sürmesinin yeterli olduğu, işyerinde mobbing gerçekleşmediğini ispat külfetinin davalıya düştüğ̈̈; tanık beyanları, sağlık raporları, bilirkişi raporu, kamera kayıtları ve diğer tüm deliller değerlendirildiğinde mobbing iddiasının yeterli delillerle ispat edildiği gözetilmeden davanın reddi hukuka aykırıdır. ${ }^{69}$

Bir diğer Yargıtay kararına göre işçinin anlattığı mobbing teşkil eden olayların tutarlılık teşkil etmesi, kuvvetli bir emarenin bulunması gerekmektedir. Kişilik hakları ve sağı̆̆ın ağır saldırıya uğraması mobbingin varlığının tartışmasız kabulünü doğurur. Öte yandan ispat kurallarının zorlanan sınırları usul hukukunda yeni arayışlara yol açmıştır. Emre işte bu anlayışın bir sonucudur. Olayların tipik akışı, tecrübe kuralları göz önüne alındığında verilecek sonuçla ispat gerçekleşir. Bir başka deyişle bu ilk görünüş ispatıdır. ${ }^{70}$

\section{SONUÇ}

Süreklilik, sistemlilik ve kasıtılık unsurlarını taşıyan mobbing kavramı yatay ve dikey hiyerarşik açılardan ele alınması gereken bir kavramdır. Türk Hukukunda işçi-işçi ilişkileri açısından ve işveren-işçi ilişkileri açısından düzenlenmiştir.

Söz konusu düzenlemeler özel hukuk ve kamu hukuku kaynaklarında yer bulmuş bulunup birbiriyle çelişmemekle birlikte uyum içinde de değildir. Bu noktadan yola çıkarak mobbing kavramının tanımlanması ve kavrama ilişkin ayrıntılı düzenlemelerin getirilmesi mobbing ile mücadelede atılacak en önemli adımdır.

Mobbing kavramının İş Kanunundaki tezahürü haklı nedenle fesih kapsamında ahlak ve iyi niyet kuralları çerçevesindedir. Buna göre ahlak ve iyi niyete uygun olmayan davranışlarla karşılaşan iş̧̧i veya işveren, iş sözleşmesinin süresini beklemek ve ihbar sürelerini beklemek sorumluluğundan kurtularak iş sözleşmesini derhal feshedebilmektedir.

İş Kanunu'ndaki bir diğer düzenleme ise eşit davranma borcu altındadır. İşveren en basit şekliyle, işçileri arasında herhangi bir ayrımcılık yapmama sorumluluğundadır. Bunun aksi davranışlar ayrımcılık tazminatı ile cezalandırılmakla birlikte. Ayrımcılık tazminatı ile kötü niyet tazminatı, sendikal tazminat vb. tazminatların verilememesi iş̧̧i açısından hak kayıplarına yol açabilmektedir. Bu noktada tazminatlarca korunması istenen menfaatlerin karşılaştırılması yerinde olacaktır. Bu noktada işe başlatmama tazminatı ve kötü niyet tazminatının ayrımcılık tazminatının aynı anda verilebilmesi gerektiği görüşündeyiz.

Mobbingin Türk Borçlar Kanunu ve Türk Medeni Kanunundaki tezahürüne göre ise; kişilik haklarının ihlali durumunda koruma davaları ve maddi-manevi tazminat davalarıyla hak aranabilmektedir. Söz konusu davalar tacizciye yönelik açılabileceği gibi tacizcinin iş̧̧i olması durumunda buna göz yuman işverene de açılabilmektedir.

Mobbingin bir diğer tezahürü ise İş Sağlığı ve Güvenliği Kanunundadır. İlgili Kanuna göre işveren işçinin sağlığı ve güvenliği adına her türlü önlemi almakla yükümlüdür. Bu önlemlerden bir tanesi de işçinin psiko-sosyal sağlığına yöneliktir. İşverenin söz konusu önlemleri almaması durumunda işçinin çalışmaktan kaçınma hakkı vardır.

Mobbingin önlenmesi adına İş Sağlığı ve Güvenliği Kanununda işverene pek çok görev yüklenmiştir. Bunların başında da risk değerlendirme gelmektedir. Günümüzde her ne kadar risk değerlendirme prosedürü fiziksel ve biyolojik riskleri göz önüne alıyor olsa da işverenler iş̧̧ileri karşı karşıya kaldıkları psiko-sosyal risklere karşı da korumak zorundadır.

Sıralanan düzenlemeler göz önüne alındığında mobbingin tanımının yapılmadığı ve doğrudan mobbinge yönelik bir düzenleme olmadığı ortaya çıkmaktadır. Bu kapsamda büyük işçi kitlelerini kapsamı altına alan 4857 sayılı iş Kanunu'nda mobbingle ilgili özel bir düzenleme öngörülmesi gerekmektedir.

Buna ek olarak psikolojik tacizin iş sağlığı ve güvenliği sorunu olarak ele alınarak işverenin eğitim ve bilgilendirme sorumluluğu, risk değerlendirme, iş sağlığı ve güvenliği önlemlerine uyulup uyulmadığını denetleme, işçilerin görüşlerini alma ve katılımlarını sağlama gibi sorumlulukları ile ilişkisinin sağlanması ve işverenin her türlü önlemi alma yükümlülüğü kapsamında bu sorumluluklarını yerine getirmesi adına yaptırımlar getirilmesi gerekmektedir.

Yargıtay kararlarına baktığımızda işçi yararına yorum yapıldığı ve ispat kolaylıkları getirildiği görülmektedir. Yargıtay geçmiş kararlarında her ne kadar kusursuz sorumluluk ekseninde kararlar alsa da günümüzde kusur sorumluluğu görüşüne geçiş yapmıştır. Kusursuz sorumluluk anlayışı her ne kadar işçi lehine olsa da hukuk tekniği açısından tartışmalıdır. Bu sebeple Yargıtay somut olaya göre yorum yapmaktadır.

\footnotetext{
${ }^{69}$ Yarg. 22. HD. 27/12/2013 E. 2013/693 K. 2013/30811; Bilgili, İş Hukukunda Mobbing, s.114

${ }^{70}$ Yarg. 9. HD.01/04/2011 8046/9717, Sümer, İş Hukuku Uygulamaları, s.280
} 


\section{KAYNAKÇA}

Adams, Andrea, Bullying at Work, Journal of Community \& Applied Social Psychology, 1997, 7

Akgeyik, Tekin; Güngör, Meltem; Uşen, Şelale ve Omay, Umut, “İşyerinde Psikolojik Taciz Olgusu: Niteliği, Yaygınlığı ve Mücadele Stratejisi”, Sosyal Siyaset Konferansları, 2009, 56

Akıncı, Şahin, Borçlar Hukuku Bilgisi, Sayram Yayınları, Konya, 2006

Arslan Ertürk, Arzu, “i̇ş Hukuku Boyutuyla Türkiye'de Psikolojik Taciz (Mobbing) ve Dünya'dan Örnekler”, Prof. Dr. Ali Rıza Okur’a Armağan, Marmara Üniversitesi Hukuk Fakültesi Hukuk Araştırmaları Dergisi, İstanbul, 2014, 20(1)

Aydın, Şule; Özkul, Emrah, “İşyerinde Yaşanan Psikolojik Şiddetin Yapısı ve Boyutları: 4-5 Yıldızlı Otel İşletmeleri Örneği”, Anadolu Üniversitesi Sosyal Bilimler Dergisi, 7(2)

Baysal, Mustafa, Çözümlerle İş Kanunu Sorunları, Seçkin Yayınevi, Ankara, 2014

Bilge, Selahattin Samet, “Mobbing Terimi ve Türk Hukuk Düzeninde İncelenmesi”, Ankara Üniversitesi Hukuk Fakültesi Dergisi, 2016, 65(4), $1245-1290$

Bilgili, Abbas, İş Hukuku Açısından Mobbing, Karahan Kitapevi, Adana, 2012

Binbir, Sinan, İş Sağlığı ve Güvenliği Kanunuyla Birlikte Yargı Kararları, Açıklama ve Örneklerle İş Kanunu, Yaklaşım Yayınları, İstanbul, 2012

Centel, Tankut, “Türk Borçlar Kanunu'nda Genel Olarak İşçinin Kişiliğinin Korunması”, Sicil ïHD, 2011, Aralık

Chappell, Duncan ve Di Martino, Vittorio, Violence at Work, International Labour Office, Genava, 2006

Çelik, Nuri, İş Hukuku Dersleri, Beta Yayınevi, İstanbul, 2016

Çokgüler, Aslı, “Onurlu Çalışma Hakkı”, Psikeart, 2014, 36

Davenport, Noa; Schwartz, Ruth Distler, Elliot, Gail Pursell, Mobbing İsyerinde Duygusal Taciz, Sistem Yayıncılık, İstanbul, 2003

Demir, Şamil, “Mobbing Olgusunun Hukuki Değerlendirmesi”, Ankara Barosu Dergisi, 2009, 67/2, ss. 139-145

Doğancı, Doğa Ekrem; Çakrak, Recep, “ Hukuki Düzenlemeler Çerçevesinde Psikoloji Taciz (Mobbing) ve İspat Yükü, Kara Tahta, 2016, 6, 77106

Erdem, Mustafa Ruhan; Parlak, Benay, “Ceza Hukuku Boyutuyla Mobbing”, Türkiye Barolar Birliği Dergisi, 2010, 88, 261-286

European Parliament, "Resolution on Harassment at the Workplace 2001/2339 (INI)", Official Journal of European Communities, 2001

Güngör, Meltem, Çalışma Hayatında Psikolojik Taciz, Derin Yayınevi, İstanbul, 2008

http://www.milliyet.com.tr/dekana-mobbing-cezasi-gundem-1270035/, Erişim Tarihi: 10.04.2017

İlhan, Ümit, “ İ̧̧yerinde Psikolojik Tacizin (Mobbing) Tarihsel Arka Planı ve Türk Hukuk Sistemindeki Yeri”, Ege Akademik Bakış, 2010, 10(4), $1175-1186$

İ̧̧yerinde Psikolojik Şiddet Taciz (Mobbing) Bilgilendirme Rehberi, https://www.csgb.gov.tr/media/2053/mobbing_2014.pdf, s.9, Erişim Tarihi: 15.02 .2016

Kaplan, Emine Tuncay, "Yeni Türk Borçlar Kanunu Hükümlerine Göre İş İlişkisinde İşçinin Kişilik Haklarının Korunması", Sicil İş Hukuku Dergisi, sayı 24, 2011

Karslıoğlu Yeni, Güldane, Mobbing: İşyerinde Psikolojik Taciz, Tük Metal, Ankara, 2013

Keser, Aşkın, Çalışma Psikolojisi, Ekin Yayınevi, Bursa, 2012

Kılıçoğlu, Mustafa, Borçlar Hukuku, Turhan Kitapevi, Ankara, 2014

Korkmaz, Fahrettin; Alp, Nihat Seyhun, Bireysel İ̧̧ Hukuku, Seçkin Yayınevi, Ankara, 2014

Leyymann, Heinz, "The Content and Development of Mobbing at Work", Eurpean Journal of Work and Organizational Psychology, 1996, $5(2)$

Limoncuoğlu, Alp, “iş̧ Hukuku Kapsamında Psikolojik Tacizin Değerlendirilmesi ve Mağdurların Kullanabilecekleri Haklar”, Türkiye Barolar Birliği Dergisi, 2013, 105

Limoncuoğlu, Alp, “İşçinin İş Sözleşmesini Psikolojik Tacize Dayalı Olarak Haklı Nedenle Feshinde Hak Düşürücü Sürenin Başlangıcı, DEÜHFD, 2013, 15, s.547-571

Namie, Gary, “Workplace Bullying: Escalated Incivility”, Ivey Business Journal, 2003, 68

Narmanlıoğlu, Ünal, İş Hukuku: Ferdi İş illişkileri I, Beta Yayınevi, İstanbul, 2014

Palaz, Serap, "Psikolojik Taciz ve Yıldırma Davranışları Üzerine Bir Araştırma: Banka Çalışanları Örneği”, Kara Tahta, 2016, 5, 19-35 
Rayner, Charlotte ve Hoel, Helge, "Workplace Bullying”, Journal of Community \& Applied Social Psychology, 1997, 10(4)

Sevimli, K. Ahmet, "Türk Borçlar Kanunu m.417 ve İş Sağlığı ve Güvenliği Işığında Genel Olarak İşçinin Kişiliğinin Korunması”, Çalışma ve Toplum Dergisi, sayı 36, 2013

Sevinçok, Levent, “Mobbing (İşyerinde Psikolojik Taciz), Kara Tahta, 2016, 5, 1-18

Sümer, Haluk Hadi, İş Hukuku, Seçkin Yayınevi, Ankara, 2016

Sümer, Haluk Hadi, İş Hukuku Uygulamaları, Seçkin Yayınevi, Ankara, 2016

Süzek, Sarper, İş hukuku, Beta Basım Yayım, İstanbul, 2013

Şahin, Serenay, "Yeni Bir Yaklaşım: İş Sağlığı ve Güvenliği’nde Mobbing Faktörünün Önemi ve Etkisi", The Journal of Academic Social Science, 2015, 3(9), 489-505

Şakar, Müjdat, Gerekçeli ve İçtihatı İş Kanunu Yorumu, Parametre, Ankara, 2015

Şenturan, Şermin, Örnek Olaylarla Örgütsel Davranış, Beta Yayınevi, İstanbul, 2014

Tınaz, Pınar, İşyerinde Psikolojik Taciz(Mobbing), Beta Yayınevi, İstanbul, 2010

Tınaz, Pınar, “Mobbing: İ̧̧yerinde Psikolojik Taciz”, Çalışma ve Toplum, 2006, 3/10

Tınaz, Pınar; Ergin, Hediye; Bayram, Hediye, Çalışma Psikolojisi ve Hukuki Boyutlarıyla İşyerinde Psikolojik Taciz (Mobbing), Beta Yayınevi, İstanbul, 2008

Tutar, Hasan, İşyerinde Psikolojik Şiddet, Platin Yayıncılık, Ankara, 2004

Türkiye Büyük Millet Meclisi, Kadın ve Erkek Fırsat Eşitliği Komisyonu, TBMM Basımevi, Ankara, 2010

Ünal, Canan, “ Karşılaştırmalı Hukuk Işığında İşyerinde Psikolojik Tacizin İşverenin İşçinin Kişiliğini Koruma ve Eşit Davranma Borcu Kapsamında Değerlendirilmesi, Legal IHD, 2013, 37

Yamada, David, "Global Perspective on Workplace Harassment Law: Proceedings of The 2004 Annual Meeting, Association of American Law Schools Section On Labor Relations and Emploment Law", Employee Rights and Employement Policy Journal, 2004, 8(1)

Yaman, Erkan, Yönetim Psikolojisi Açısından İşyerinde Psikolojik Şiddet: Mobbing, Nobel Yayın Dağıtım, Ankara, 2009

Yavuz, Cevdet, Borçlar Hukuku Dersleri (Özel Hükümler), Beta Yayınevi, Ankara, 2013

Yıldız, Gaye Burcu, İşverenin Eşit Davranma Borcu, Ankara, 2008

Zapf, D.; Konrz, C.; Kulla, M., "On the Relationship Between Mobbing Factors and Job Content The Social Work Environment and Healthe Outcomes", European Journal of Work and Organizational Psychology, 5 